\title{
Article
}

\section{William Stukeley: an eighteenth-century phenomenologist?}

\author{
Peterson, Rick \\ Available at http://clok.uclan.ac.uk/330/ \\ Peterson, Rick ORCID: 0000-0002-4185-1288 (2003) William Stukeley: an \\ eighteenth-century phenomenologist? Antiquity, 77 (3). pp. 394-400. ISSN \\ o003598X
}

It is advisable to refer to the publisher's version if you intend to cite from the work.

For more information about UCLan's research in this area go to

http://www.uclan.ac.uk/researchgroups/ and search for <name of research Group>.

For information about Research generally at UCLan please go to

http://www.uclan.ac.uk/research/

All outputs in CLoK are protected by Intellectual Property Rights law, including Copyright law. Copyright, IPR and Moral Rights for the works on this site are retained by the individual authors and/or other copyright owners. Terms and conditions for use of this material are defined in the policies page.

\section{CLoK}

Central Lancashire online Knowledge www.clok.uclan.ac.uk

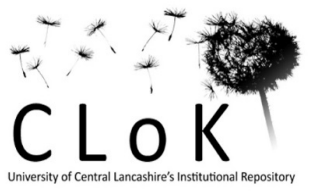




\title{
William Stukeley: an eighteenth-century phenomenologist?
}

\author{
Rick Peterson*
}

Phenomenology is the modern theoretical archaeologist's word for the appreciation of how a prehistoric monument relates to its landscape. The author shows how the one of the earliest antiquaries, William Stukeley, pre-echoed some of its principles methods and thinking.

Keywords: Avebury, William Stukeley, landscape, phenomenology.

\section{Introduction}

The work of the early eighteenth-century antiquary William Stukeley is well known, particularly his recording of the complex of prehistoric monuments around Avebury in north Wiltshire, one of the most spectacular and intensively studied prehistoric sites in England. The complex comprises the large henge and multiple stone circle in Avebury village itself and two megalithic avenues: the West Kennet avenue to the south-east (which linked the smaller stone and timber circle known as The Sanctuary to the Avebury circles), and the Beckhampton Avenue to the west. Between the two avenues and to the south of the main henge is the large mound of Silbury Hill, and the recently discovered palisade enclosures at West Kennet (Whittle 1997). William Stukeley (16871765) was one of the first people to appreciate these monuments and the fieldwork he carried out has been re-examined repeatedly. Colt Hoare (1821: 65-78), Crawford, Keiller (Crawford \& Keiller 1923; Smith 1965) and Ucko et al. (1991) have all used Stukeley's records to try and elucidate the more fragmentary remains surviving at later dates. Piggott (1985), Ucko et al. (1991) and Haycock (1999) have also tried to explain the intellectual background to the fieldwork and to place it in its historical context. Each of these re-appraisals has given us a slightly different image of Stukeley, viewed through the interests of the various writers.

This paper arose from my personal encounter with the Stukeley archive, as part of an ongoing research project centred on the Avebury complex and in particular the Beckhampton Avenue in Longstones field, west of Avebury (Gillings, Pollard \& Wheatley 2000). This project, a collaborative venture between the Universities of Leicester, Newport and Southampton, aims to explore the context and sequence of late Neolithic monument development in the Avebury landscape (Pollard \& Gillings 1998: Pollard, Gillings \& Wheatley 1999). While I will not do more than touch upon the detailed discussions of Stukeley's ideas and motivations offered by Piggott (1985: 79-109), Ucko et al. (1991: 48-59, 74-98) and Haycock (1999), I want to bring out a strand of Stukeley's thinking that is particularly visible in his Avebury fieldwork.

* SCARAB Research Centre, Caerleon Campus, University of Wales College Newport, PO Box 179, Wales NP18 $3 Y G$ (Email:Rick.Peterson@newport.ac.uk) 
This is the parallel noted by Haycock (1999: 68), with some recent archaeological approaches to monuments and landscapes (for example Tilley 1994; Richards 1996). Grouped together under the general term 'phenomenological', this work is concerned with bodily experiences of landscape and place, as distinct from interpretations mediated by the more two dimensional representations of space employed in traditional cartography.

\section{The Stukeley Archive}

Stukeley worked at Avebury between 1719 and 1724. The surviving notes from this fieldwork can be divided into four main types: there are pen and wash drawings of 'prospects', views of the surviving parts of the Avebury monuments and their eighteenth-century landscape settings (Bodl. MS Gough Maps $231 \mathrm{f} 223 \mathrm{r}$, for example); there are pages, often discontinuous and fragmentary, of written field notes (such as Bodl. MS Gough Maps $231 \mathrm{f36v}$ ); there is a description of the monument in the incomplete and unpublished manuscript entitled The History of the Temples of the Ancient Celts (Bodl. MS Eng. Misc. c323); and there is the published account of the site in Avebury: A Temple of the British Druids (Stukeley 1743). As both Piggott (1985: 97-109) and Ucko et al. (1991: 83-92) have pointed out, Stukeley's vision of Avebury was not constant, but two of his understandings of the monumental complex have become particularly well-known. One scheme, probably the earliest, saw the north and south circles within Avebury as temples to the moon and sun respectively, the outer circle at Avebury as a sacred space surrounding these temples, with a pair of symmetrical stone avenues joining this space to a temple of Ertha or the earth at the Sanctuary and a temple of Mercury, or the Manes (spirits of the underworld) in a corresponding position at the end of the Beckhampton Avenue. The second scheme saw the circles at Avebury, representing the existence of God, crossed by a serpent, which represented the force of creation, formed from the two avenues, with the Sanctuary as the serpent's head. It is clear from the surviving field notes (Bodl. MS Gough Maps $231 \mathrm{f46v}$, for example) that Stukeley continued to vacillate between aspects of these two schemes, and to consider many other ideas, during the 1720s.

Most discussions of Stukeley's changing ideas have tended to revolve around two themes. The relative chronology of the two major schemes has been debated, with a general consensus that while the classically inspired arrangement of temples was probably earlier, the ring and serpent was certainly in Stukeley's mind before 1724. The second area for discussion is the extent to which Stukeley was influenced by his idealised schemes for the monuments to manipulate the data from his fieldwork. This work has drawn upon the few two-dimensional representations Stukeley prepared of his ideas to illustrate how he sought first symmetry and then the form of his serpent in the remains (Piggott 1985: 106-7, for example). These discussions both illustrate a commonplace about Stukeley, that his recording was influenced by whichever understanding of the monument was uppermost in his mind at the time, and, I believe, fundamentally misrepresent the way in which Stukeley recorded and interacted with the Avebury complex. The great majority of Stukeley's field records are not plans, in the modern archaeological sense, at all. His primary recording tool appears to have been the 'prospect', views of the current state of the monuments in their landscape. Figure 1 shows one such prospect, of Beckhampton and the Longstones Cove from the north-west.

These were combined with field notes containing many compass bearings to allow the construction of generally three-dimensional views of the monument complex. These more synthetic 


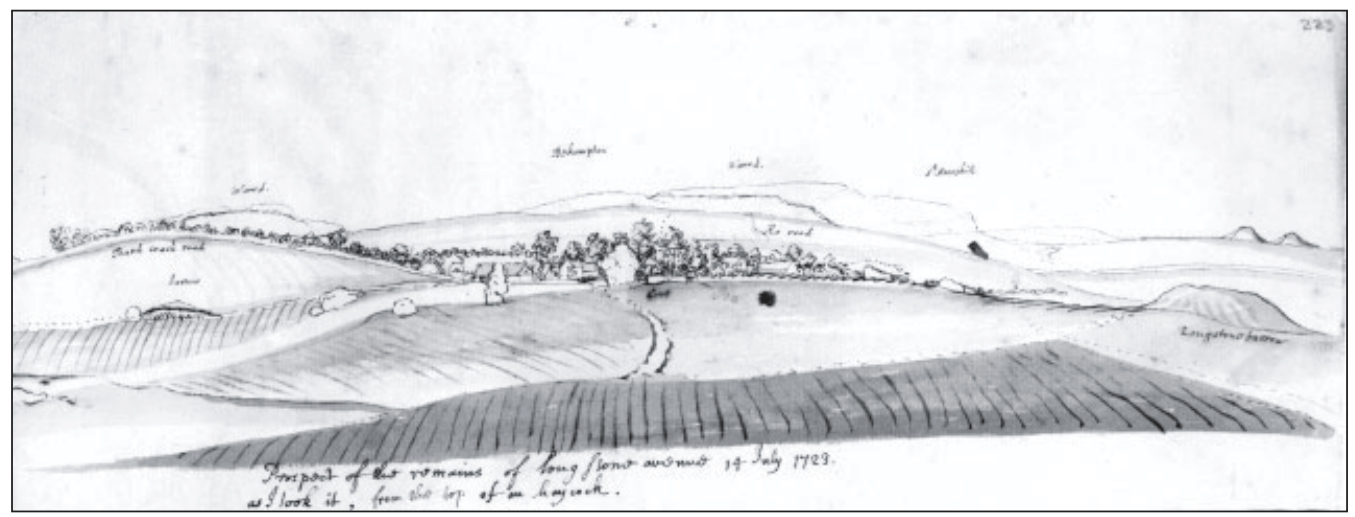

Figure 1 'Prospect of the remains of Long Stone avenue 14 July 1723. as I took it, from the top of an haycock.' (Bodl. MS Gough Maps 231, f223r, reproduced by permission, Bodleian Library, University of Oxford)

views have a strange chronological ambiguity about them, the restored prehistoric circles and avenues march across a visibly eighteenthcentury landscape, complete with field boundaries, buildings and roads (see, for example, Ucko 1991, plates 26 and 65). Even in those instances where Stukeley did prepare Cartesian plots of specific parts of the complex, especially the Avebury circles, he was careful to add the important third dimension to his final renderings of this information. Most striking of all is his use of compass bearings and landscape sketches to construct a remarkable series of 'circular views'. These drawings show the area around certain key points in the monument complex in a way completely removed from the traditional landscape 'prospect'. The horizon around the point in question is illustrated as a continuous circle, allowing a view of landscape settings and alignments in all directions to be represented simultaneously (see Figure 2).

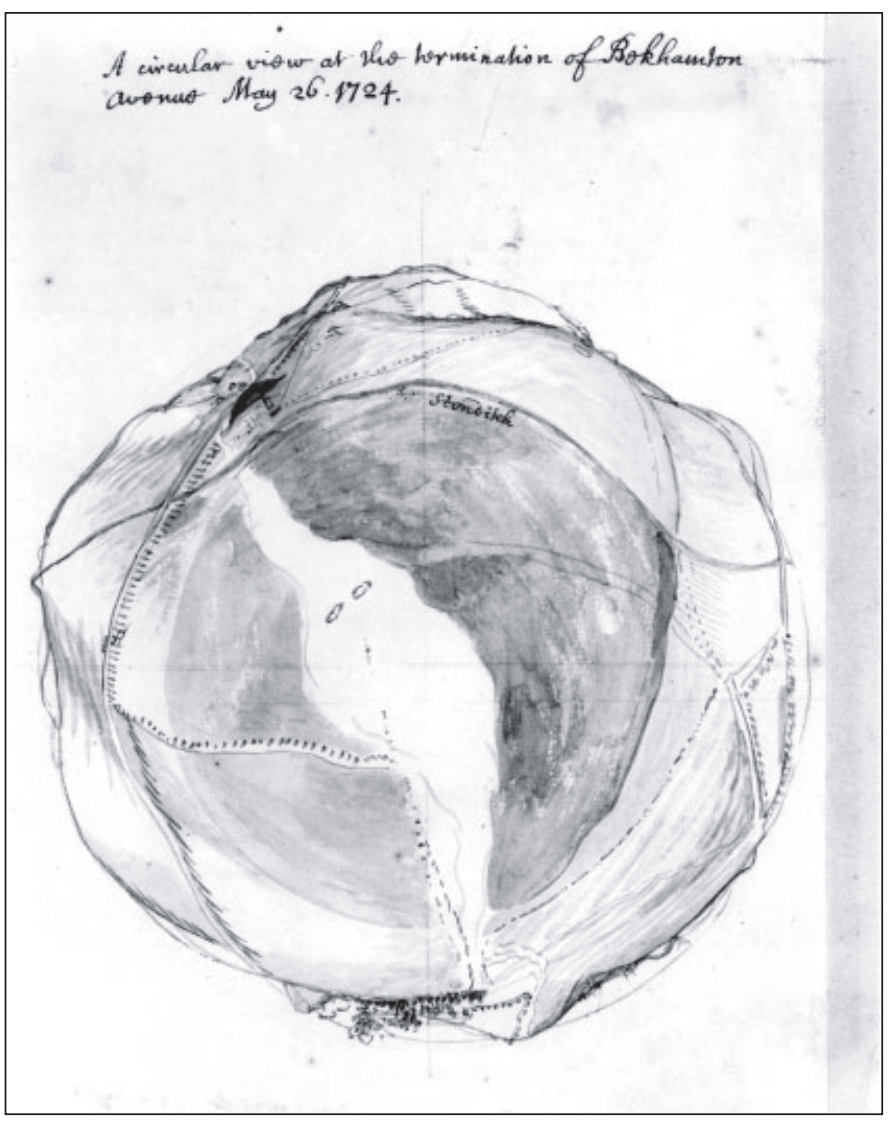

Figure 2 'A circular view of the termination of Bekhamton avenue May 26. 1724' (Bodl. MS Gough Maps 231, f46r, reproduced by permission, Bodleian Library, University of Oxford) 


\section{Stukeley and the landscape}

What these different types of record seem to illustrate is that Stukeley's understanding of the Avebury complex was significantly different from the abstracted plan view of later traditions. He regarded the monuments as having been carefully set into a particular landscape, and as drawing on that landscape to achieve certain effects. This is a view which we are more used to hearing articulated as part of recent phenomenological approaches to ancient landscapes. Stukeley's work includes numerous passages which echo the concerns of writers like Chris Tilley (1994) and Colin Richards (1996). For example, contrast the following:

'... as soon as you mount the high ground going across from South Street to the $w$ [est] entrance from horslip you see the purpose and direction of the avenue. Long Stones cove pointing directly to the utmost end of the valley below. the hills to the right \& the left which open themselves very finely like wings Cheril Hill and the great ridge whereupon stands Oldbury to the right, Fowler's Hill \& St Ann's to the left, these goe strait forwards o by their successive differences diminish to the eye in ... and sight to the utmost extremity with an awful yet of lovely appearance especially in the evening.' (Bodl. MS Gough Maps $231 \mathrm{f} 3$ )

'I would suggest that the duality expressed in this architecture refers to the immediate topography, the two areas of high ground that form the valley sides and the two river systems that enclose the land on which the monuments are situated. Under these circumstances an exact correspondence occurs between the natural world and the architecture of the henge monument.' (Richards 1996: 330-1)

'Tis plain from sight of the groundplot that the Scheme which the architect prepard, as the rule \& model of this stately composure, was adjusted with great skill \& judgement, both with regard to use \& to produce a proper effect.' (Bodl. MS Eng. Misc. c323 139)

'Whatever the precise chronological relationship, the lack of precise incorporation into the Cursus bank is of considerable symbolic significance. This was intended to be the case: the monument should be both incorporated into the Cursus banks and maintain its identity and visual impact by being differentiated from them.' (Tilley 1994: 181.)

"tis very manifest that one intention in the site of Abury was by the interposition of hills to hinder the vulgar from understanding the scheme.' (Bodl. MS Gough Maps 231 $\mathrm{f} 33 \mathrm{v})$

'... the entire layout of the Cursus seems to intended to exclude outsiders: only for those inside the great enclosure was the design of the monument apparent.' (Bradley in Barrett et al. 1991: 58)

Specific points about the location of the main circles were recently highlighted in the work of Aaron Watson on Avebury itself. These ideas were also brought out by Stukeley as the following quotations show (Watson first): 
'The banks mask the ground immediately around the monument, effectively removing immediate frames of reference and emphasising the distant circle of hills. Without this depth of view, the observer cannot easily judge distance to the skyline ... and the way in which these hills are framed by the earthwork creates the impression that the backdrop of hills is wrapped in a circle around the monument. This is a contrived illusion which is peculiar to the henge, and it contrasts entirely with the experience of moving through the wider landscape.' (Watson 2001: 306)

"Tis a fine scituation, for this spot is a plain or rather a gently rising knoll, in the midst of a large concavity 5 or 6 mile in diameter, for you descent to it from on all sides, from hills which overlook it two or three miles distant, so that tis a sort of large Theatre, admirably well chose for the magnificent purpose.'(Bodl. MS Eng. Misc. c323 119)

'... the only level ground within the henge extends from the Southern Entrance towards the centre of the monument. This effectively divides the interior in half with the other three entrances being situated downslope from the centre. This arrangement not only seems to have been deliberate, but was used to great effect.' (Watson 2001: 301)

I observe too that the plain of the ground has naturally a ridg or rising going from Northwest to Southeast exactly, with the Diametrical line upon which the two Centres of the two Temples stand, \& that both ways from thence the water falls by an easy descent, the middle of the temples being upon this highest ground, which is an admirable contrivance.' (Bodl. MS Eng. Misc. c323 137)

Like his recent successors, Stukeley appears to have used the Cartesian data of traditional surveys to create different representations of the monuments which were more concerned with perceptions from within the landscape than the two dimensional plan view. His 'circular views' prefigure the work of Vicki Cummings (2001: especially 92-106) on the representation of landscapes through non-traditional imagery. I have not been able to find any notes in the Stukeley archive which throw any light on the origins of these remarkable drawings, and the fact that Stukeley chose not to have any of them engraved for publication probably indicates that he regarded them primarily as research drawings. Cummings makes a relevant distinction between her strikingly similar 360 degree diagrams (see Figure 3) as useful research tools and the difficulty of using them to present data to an audience unused to reading such nontraditional images.

'The schematic $360^{\circ}$ diagrams proved invaluable in the analysis of the data, since they are quick to produce and it is easy to compare sites by examining these pictures. Broad differences between monument types are reinforced by these schematics... However, although these diagrams were useful for the analysis, it was clear that they are not particularly easy to 'read' and would be of limited use in the presentation of the data.' (Cummings 2001: 97)

The parallels which have been drawn out between Stukeley's fieldwork and the recent interest in the phenomenology of landscape can obviously only be carried so far. Haycock (1999: 73-5) discusses Stukeley's interest in landscape chiefly as a rhetorical strategy, part of 
a political and philosophical account, a published piece of writing, which was designed to induce a contemplation of the ideals and divinity, linked to the purity of rural life as against the complexities of urban politics. However, Stukeley's formal response to the landscape and monuments occurred at a much earlier date than the publication of Abury in 1743. As demonstrated above, it is his fieldwork, his first encounters with the monument complex, which

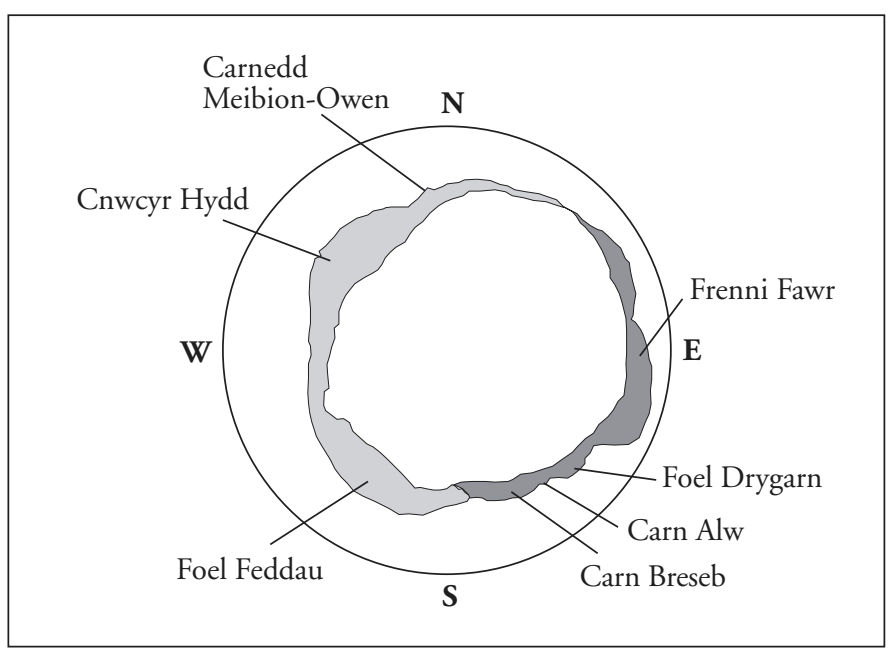

Figure 3 The landscape around Bedd yr Afanc, Pembrokeshire, drawn in the field to record the landscape setting of the monument (Cummings 2001, fig. 5.3) are dominated by the concerns which seem so close to the concerns of phenomenology. Ingold (2000: 220-41) has extensively discussed the interconnections between the processes of finding a way around a landscape and the act of mapping that landscape. Of particular relevance is a distinction Ingold (2000: 231-5) establishes between mapping as the recounting of a historical account of an encounter with a place and map-making as the production of a summary of the results of that encounter, shorn of its historical details. Ingold (following de Certeau 1984) sees a historical change as, between the fifteenth and seventeenth centuries, the abstracted plan view of the map began to replace the remembered detail of the encounter. The abstracted plan view was novel enough in the early eighteenth century for Stukeley to be able to move freely between plans, prospects and narrative notes, between mapping and map-making, as he struggled to capture those parts of the Avebury landscape which engrossed him.

I think that this is why Stukeley, who is often presented as being at the beginning of the rationalist, 'scientific' way of working in archaeology (Burl 1979: 48-50, for example), should have so many points of contact with approaches explicitly designed to get past the perceived limitations of that same modern, distanced view of the world. Martin Heidegger, whose thinking lies behind much of Tilley's characterisation of phenomenology, held that the process of overcoming this distanced, rational view of the world typified by modern science was a process of recovering a more integrated, embedded encounter with specific things, one grounded in the pre-modern past (Heidegger 1927: 99, for example, and see also Rorty 1991: 41-49). The re-use of so many of Stukeley's techniques could be thought of as an example of this process. Tilley or Richards overcome the limitations of the two dimensional plan view by reinventing Stukeley's methods of recording an encounter within the monument and its landscape. Stukeley, on this account, was not the early example of the modern fieldworker presented by Burl, but the end of an earlier tradition. Philip Croker's surveys for Colt Hoare (1821, plates X \& XIII, for example) mark the beginning of the dominance of the plan view in archaeological survey. In attempting to escape this dominance it is perhaps not surprising that archaeologists have been led back to some of Stukeley's techniques. 


\section{Rick Peterson}

\section{Acknowledgements}

This work was carried out as part of the five year 'Longstones' project, exploring the later Neolithic monuments of the upper Kennet valley, funded by a major grant from the AHRB. This paper has benefited enormously from comments from Vicki Cummings, Mark Gillings, Josh Pollard, Julia Roberts, Julian Thomas, Aaron Watson and two Antiquity referees. Thanks are also due to Vicki Cummings for permission to reproduce Figure 5.3 from her $\mathrm{PhD}$ thesis, to Aaron Watson for allowing me to see his Composing Avebury paper in advance of publication and to the Keeper of Special Collections and Western Manuscripts, Bodleian Library, University of Oxford for permission to reproduce Figures 1 and 2.

\section{References}

BarretT, J., R. Bradley \& M. GReEN 1991. Landscape, monuments and society. The prehistory of Cranbourne Chase. Cambridge: Cambridge University Press.

Burl, A. 1979. Prehistoric Avebury. New Haven \& London: Yale University Press.

CerteAu, M. DE 1984 The practice of everyday life. Berkeley: University of California Press.

Colt Hoare, Sir R. 1821. The ancient history of Wiltshire (Vol 2). London: Lackington, Hughes, Harding, Maver \& Lepard.

Crawford, O.G.S \& A. Keiller 1923. Wessex from the air. Oxford: Oxford University Press.

Cummings, V. 2001. Landscapes in transition? Exploring the origins of monumentality in south west Wales and south west Scotland. Unpublished Ph.D thesis, School of History and Archaeology, University of Wales Cardiff.

Gillings, M., J. Pollard \& D. Wheatley 2000 The Beckhampton Avenue and a 'new' Neolithic enclosure near Avebury: an interim report on the 1999 excavations. Wiltshire Archaeological and Natural History Society Magazine 93, 1-8.

HAYCOCK, D. 1999 'A small journey into the country': William Stukeley and the formal landscapes of Stonehenge and Avebury, in M. Myrone \& L. Peltz (eds) Producing the past: aspects of antiquarian culture and practice 1700-1850. Aldershot: Ashgate, 67-82.

Heidegger, M. 1927. Being and time (trans. J. Macquarrie \& E. Robinson). New York: Harper \& Row (1962).

INGOLD, T. 2000 The perception of the environment: essays in livelihood, dwelling and skill. London: Routledge.
PIgGotT, S. 1985. William Stukeley: an eighteenth century antiquary (2nd Ed). London: Thames \& Hudson.

Pollard, J. \& M. Gillings. 1998. Romancing the stones, towards a virtual and elemental Avebury. Archaeological Dialogues 5 (2), 143-64.

Pollard, J., M. Gillings \& D. Wheatley. 1999 Pulling back the covers on sleeping stones: recent excavations on the Beckhampton Avenue, Avebury. Lithics 20, 31-2.

RichARDS, C. 1996. Henges and water: towards an elemental understanding of monumentality and landscape in late Neolithic Britain. Journal of Material Culture 1 (3), 313-336.

RoRTY, R. 1991 Essays on Heidegger and others: philosophical papers 2. Cambridge: Cambridge University Press.

SMITH, I.F. 1965. Windmill Hill and Avebury: excavations by Alexander Keiller. Oxford: Clarendon Press.

STUKELEY, W. 1743 Abury: a temple of the British druids. London: W. Stukeley.

Tilley, C. 1994. A phenomenology of landscape: places, paths and monuments. Oxford: Berg.

UCKO, P.J., M. Hunter, A.J. Clark \& A. David. 1991. Avebury reconsidered: from the 1660s to the 1990s. London: Unwin Hyman.

Watson, A. 2001 Composing Avebury. World Archaeology 33 (2), 296-314.

WhitTle, A.W.R. 1997. Sacred mound, holy rings: Silbury Hill and the West Kennet palisade enclosures: a later Neolithic complex in north Wiltshire. Oxford: Oxbow. 